\title{
Indian Rice Husk Ash - Improving the Mechanical Properties of Concrete: A Review
}

\author{
${ }^{1}$ Swami Nathen. A.N, ${ }^{2}$ Robert Ravi.S \\ ${ }^{1}$ Assistant Professor, Sree Sakthi Engineering College, Karamadai, Coimbatore 641104, \\ ${ }^{2}$ Head and Professor, SSM Institute of Engineering and Technology, Dindugal, Tamil Nadu
}

\section{ABSTRACT}

The objective of this paper is to study a review of Indian Rice Husk Ash (RHA) as a partial cement replacement in different percentage and performance of strength and durability of RHA blended concrete. The demand for producing durable construction material is the result of the environmental pollution. Supplementary cementitious materials prove to be effective to meet most of the requirements of durable concrete, RHA is available in plenty to other supplementary materials like silica fume and fly ash, Due to its high pozzolanic activity, and the strength and durability of concrete are improved. This paper presents an over view of the work carried out on the use of Indian RHA to improve the strength and durability of concrete

Keyword: strength, durability, RHA, chemical and physical properties
\end{abstract}

\section{INTRODUCTION}

India is an agricultural country producing plenty of rice husks which is mostly used as fuel in the boilers for processing paddy, producing energy through direct combustion or by gasification, about 122 million tonnes of paddy are produced annually by India (Jayanti Rajput et.al 2013), about $20-22 \%$ rice husk is generated from paddy and 20$25 \%$ of the total husk becomes as RICE HUSK ASH after burning, each ton of paddy produces about $40 \mathrm{~kg}$ of rice husk ash. The Rice husk creates great environment threat causing severe damage to the land and the atmosphere. Many methods are being thought for disposing them, the best method to dispose them is; use of RHA as cement replacement material. Replacement of cement by RHA has become a common recommendation almost in all the international building codes. Owing to its technological and economical advantages, it has gained its importance. It is understood that, in order to produce RHA, a controlled incineration and duration of burning has to be maintained. Moreover, the form of silica obtained after combustion of RHA depends on the temperature and duration of combustion of rice husk.

RHA is a agro waste material, $20 \mathrm{~kg}$ of rice husk are obtained for $100 \mathrm{~kg}$ of rice, and rice husk is the outer covering of the grain of rice plant with a high concentration of silica, more than 80 85\% (Siddique., 2008), RHA concrete is like Fly ash concrete with regards to its strength and durability development but with a higher pozzolonic activity, it helps the pozzolonic reaction to occur at early ages rather than later as is the case with other replacement cementing materials (Malhotra ., 1993).
Rice husk ash gives many advantages due to its various properties. The influence and its physic mechanical properties were studied by Mauro M. Tashima et.al. 1985), Rice husk ash was prepared under controlled incineration so that the last product formed to engineering qualities in terms of physical and chemical properties(Moayad N. Al-Khalaf et al. 1984). The incorporation of $10 \%$ RHA as partial replacement of cement on the compressive strength of concrete was compared it with silica fume concrete for the same 10\% replacement, the RHA concrete had a compressive strength of $38.6 \mathrm{Mpa}$ compared with $36.4 \mathrm{Mpa}$ for the control concrete and for SF concrete it was 44.4Mpa(Zhang et al. 1996)

Table 1: Comparision Of Chemical Properties Of Rha From Various

Locations

\begin{tabular}{|l|l|l|l|l|}
\hline $\begin{array}{l}\text { Constitue } \\
\mathrm{nt}\end{array}$ & $\begin{array}{l}\text { India } \\
(\%)\end{array}$ & $\begin{array}{l}\text { Malaysi } \\
\mathrm{a}(\%)\end{array}$ & $\begin{array}{l}\text { Brazi } \\
1(\%)\end{array}$ & $\begin{array}{l}\text { Netherland } \\
\text { s }\end{array}$ \\
\hline $\mathrm{SiO}_{2}$ & $\begin{array}{l}90.9 \\
9\end{array}$ & 93.01 & 92.90 & 86.9 \\
\hline $\mathrm{Al}_{2} \mathrm{O}_{3}$ & 2.90 & 0.21 & 0.18 & 0.84 \\
\hline $\mathrm{Fe}_{2} \mathrm{O}_{3}$ & 0.30 & 0.21 & 0.43 & 0.73 \\
\hline $\mathrm{CaO}$ & 0.89 & 0.41 & 1.03 & 1.4 \\
\hline $\mathrm{K}_{2} \mathrm{O}$ & 0.56 & 2.31 & 0.72 & 2.46 \\
\hline $\mathrm{MgO}$ & 0.96 & 1.59 & 0.35 & 0.57 \\
\hline $\mathrm{Na}_{2} \mathrm{O}$ & 0.10 & - & 0.02 & 0.11 \\
\hline $\mathrm{SO}$ & 0.2 & - & 0.1 & - \\
\hline $\mathrm{LOI}_{3}$ & 4 & 2.36 & - & 5.14 \\
\hline
\end{tabular}

\section{PROPERTIES OF INDIAN RHA}

RHA is a very fine material. The average particle size of RHA ranges from 5 to $25 \mu \mathrm{m}$, 
physical properties values as reported by few authors are given below (Table-2).

RHA is a very rich in silica content. Silica content in RHA is generally more than $80-85 \%$. Chemical composition of RHA as reported by few authors is given below (Table 3), For RHA to be used as pozzolon in cement concrete, it satisfies requirements for chemical composition of pozzolons as per ASTM C618. The combined proportion of silicon dioxide, alu min iu m oxide and iron oxide in the ash should not be less than $70 \%$ and LOI should not exceed $12 \%$ as stipulated in ASTM requirements.

\section{2: Physical Properties Of Indian Rha}

\begin{tabular}{|c|c|c|}
\hline property & Mehta et al & Nagrale et al., \\
\hline Mean particle size & - & $63.8 \mu \mathrm{m}$ \\
\hline Specific gravity & 2.06 & 2.11 \\
\hline $\begin{array}{c}\text { Fineness passing } \\
45 \mu \mathrm{m}\end{array}$ & $99 \%$ & $98 \%$ \\
\hline
\end{tabular}

Table 3: Che mical Composition Of Indian Rha

\begin{tabular}{|l|l|}
\hline \multicolumn{1}{|c|}{ Constituents } & percentage \\
\hline $\mathrm{SiO}_{2}$ & 90.99 \\
\hline $\mathrm{Al}_{2} \mathrm{O}_{3}$ & 2.90 \\
\hline $\mathrm{Fe}_{2} \mathrm{O}_{3}$ & 0.3 \\
\hline $\mathrm{CaO}$ & 0.89 \\
\hline $\mathrm{MgO}$ & 0.96 \\
\hline $\mathrm{Na}_{2} \mathrm{O}$ & 0.10 \\
\hline $\mathrm{K}_{2} \mathrm{O}$ & 0.56 \\
\hline $\mathrm{SO}_{3}$ & 0.24 \\
\hline $\mathrm{LOI}$ & 4 \\
\hline
\end{tabular}

\section{EXPERIMENTAL} INVESTIGATIONS

\subsection{Corrosion Properties}

Saraswathy et al., (2007) investigated the corrosion performance of concrete made with $0,5,10,15,20,25$ and $30 \%$ RHA as partial replacement of cement. They have monitored the open circuit potential measurements with reference to saturated calomel electrode periodically with time as per ASTM C876, from their study it can be observed that the time of cracking were 42,72 , and 74 hours for concrete made with 0,5 , and $10 \%$ RHA, However, no cracking was observed for concrete with $15,50,25$, and $30 \%$ RHA even after 144 hour of exposure. In contrast, ordinary Port land cement concrete, the specimen was cracked after only 42 hours of exposure in $5 \% \mathrm{NaCl}$ solution. From the above result it can be concluded that the incorporation of RHA up to $30 \%$ replacement level reduces the chloride penetration, decreases permeability, and improves strength and corrosion resistance properties.

\subsection{Strength Properties}

Chandan Kumar et al, (2012) Reported that the comparative study on RHA concrete with various replacement percentages of RHA showed that a replacement level of $7.5 \%$ RHA in concrete perform well and shows better compressive strength than other replacements.

Subash et al., (2010) Reported that $20 \%$ replacement of RHA by mass of cement shows about $18 \%$ increment of compressive strength of concrete, The addition of RHA for the concrete decreases the water absorption of concrete, There was around $11 \%$ reduction in surface water absorption with the $20 \%$ of RHA replacement compared to control specimen, thereby durability increases.

Ghassan Abode Habeeb et al., (2010) Reported that the compressive strength of the blended concrete with $10 \%$ RHA has been increased significantly, and for up to $20 \%$ replacement could be valuably replaced by cement without adversely affecting the strength. Increasing RHA fineness enhances the strength of blended concrete

Mahmud et al., (1996) Inclusion of RHA as partial replacement of cement enhances the compressive strength of concrete, but the optimum replacement level of OPC by RHA to give maximum long term strength enhancement has been reported between $10 \%$ up to $30 \%$.

M.S.Is mail and A.M.Waliuddin, 1996, carried out compressive strength test on various concrete mixes with varying \% of RHA. They found that for all the mixes the optimum dosage level of rha was $20 \%$, the compressive strength is presented in table 4.

Table: 4 Compressive strength of RHA concrete (Is mail, M.S., A.M.W aliuddin, 1996)

\begin{tabular}{|c|c|c|c|c|c|c|c|}
\hline M & RH & \multicolumn{6}{|c|}{ Compressive Strength in Mpa } \\
\cline { 4 - 8 } & $\begin{array}{c}\text { A } \\
\text { Cont } \\
\text { ent }\end{array}$ & $\begin{array}{c}1 \mathrm{~d} \\
\text { ay }\end{array}$ & $\begin{array}{c}3 \mathrm{da} \\
\text { ys }\end{array}$ & $\begin{array}{c}7 \mathrm{da} \\
\text { ys }\end{array}$ & $\begin{array}{c}28 \mathrm{~d} \\
\text { ays }\end{array}$ & $\begin{array}{c}\text { 90d } \\
\text { ays }\end{array}$ & $\begin{array}{c}180 \mathrm{~d} \\
\text { ays }\end{array}$ \\
\hline $\mathrm{M}$ & $0 \%$ & 19. & 26. & 30. & 39.6 & 44.1 & 45.7 \\
1 & & 1 & 7 & 2 & & & \\
\hline $\mathrm{M}$ & $20 \%$ & 17. & 24. & 29. & 40.6 & 45.2 & 46.9 \\
2 & & 3 & 5 & 8 & & & \\
\hline $\mathrm{M}$ & $20 \%$ & 17. & 24. & 30. & 41.0 & 46.1 & 48.1 \\
3 & & 8 & 5 & 5 & & & \\
\hline $\mathrm{M}$ & $20 \%$ & 18. & 25. & 32. & 41.7 & 47.3 & 49.8 \\
4 & & 1 & 2 & 1 & & & \\
\hline
\end{tabular}

\subsection{Durability Properties}

Kartini et al., (2008) Reported that RHA concrete improves the durability of concrete, the water absorption and ISA values of RHA concrete are lower than the control OPC concrete. These results emphasize the beneficial effect of 
incorporating RHA to increase the durability of concrete.

Karthini et al., (2010) suggested that the permeability of concrete can be reduced by the replacement of OPC with RHA; however concrete with $20 \%$ and $30 \%$ RHA replace ment levels are 3-7 times less permeable than OPC.

Anwar et al., (2001) experimentally proved that the ratio of chloride iron penetrability in RHA concrete was lower than that of OPC concrete. Addition of no ground RHA did not show any remarkable variation in the penetration of chloride ions. The incorporation of finely ground RHA in concrete lowered the rabid chloride penetrability of concrete, based on the type and the inclusion level of RHA.

Salas et al., (2009) stated that the reduction in pore size and permeability can be achieved by lowering the average pore diameter of the cement mix. In order to reduce the pore diameter RHA can be introduced in to the cement paste, apart from significantly lowering permeability and pore size, it also lowered the penetrability of chloride ions in the concrete mix.

\subsection{Comparison of compressive strength by} various researchers

\begin{tabular}{|l|l|l|l|l|l|}
\hline Author & $\begin{array}{l}\text { Chand } \\
\text { ankum } \\
\text { ar et.al }\end{array}$ & $\begin{array}{l}\text { K.Kar } \\
\text { thini } \\
\text { et.al }\end{array}$ & $\begin{array}{l}\text { Habeeb } \\
\text { et.al(20 } \\
\text { 09) }\end{array}$ & $\begin{array}{l}\text { Patnaik } \\
\text { uni } \\
\text { chandan } \\
\text { kumar } \\
\text { et.al }\end{array}$ & $\begin{array}{l}\text { Ameer } \\
\text { uddins } \\
\text { haik } \\
\text { et.al }\end{array}$ \\
\hline $\begin{array}{l}\text { Grade } \\
\text { of } \\
\text { concret } \\
\text { e }\end{array}$ & M20 & M25 & M30 & M30 & M25 \\
\hline $\begin{array}{l}\text { Compr } \\
\text { essi ve } \\
\text { Strengt } \\
\text { h at 28 } \\
\text { days } \\
\text { curing }\end{array}$ & 32.33 & 33.5 & 41.9 & 32.33 & 36.89 \\
\hline $\begin{array}{l}\text { Optimu } \\
\text { m \% } \\
\text { Replace } \\
\text { ment }\end{array}$ & $7.5 \%$ & $30 \%$ & $20 \%$ & $7.5 \%$ & $10 \%$ \\
\hline
\end{tabular}

\section{CONCLUDING REMARKS}

There are huge amounts of RHA produced as by-product from the Indian rice processing mills, mainly in India, which are disposed to environment without any return price. Thereafter, disposal cost is increased in order to transport this ash: also a large land area becomes useless and the fertility of land is reduced. So the problem can be solved or minimised by properly utilising the RHA through the production of cement or concrete as well as silica, Because RHA contains a large amount of silica and also exhibits excellent pozzolonic property. In fact incorporation of RHA either in cement or in concrete not only fulfils the demand of cement but also makes a role in production of durable concrete. The strength development of concrete produced with a particular level of RHA replacement is the same or higher as compared to OPC concrete. Furthermore a valuable cement and energy saving consideration could be performed by proper utilization of RHA in the production of cement or concrete that can be beneficial for the present demand of concrete industry.

\section{REFERENCES}

[1]. Siddique, F. 2008, Waste materials and by products i concrete: with 174 tables. Springer press.

[2]. Ganesan, K., K.Rajagopal, 2008, Rice Husk Ash Blended Cement: Assessment of Optimum level of replacement for Strength and Permeability properties of concrete. Construction and Building materials, 22(8):1675-1683.

[3]. Malhotra, V.M. 1993, Fly ash, slag, Silica fume, and Rice Hush Ash in concrete: A review, concrete international. 15(4): 2-28.

[4]. Saraswathy, V. And H. Song, 2007. Corrosion performance of Rice Husk Ash Blended Concrete. Construction and Building materials, 21(8): 1779-1784

[5]. M.M. Tashima, C.A.R. Silva, J.L.Akasaki and M.B. Barbosa, "Influence of Rice Husk Ash in mechanical characteristics of concrete," supplementary cementing materials, 1985, pp. 780-790

[6]. M.N. Al-khalaf and H.A. Yousift, Use of Rice husk Ash in concrete" The international journal of cement composites and Light weight concrete, Vol. 6, No. 4, 1984, pp.241-248.

[7]. Saraswathy V., \& Song, H., 2007. Corrosion performance of Rice Husk Ash blended concrete, Construction and building materials, 21(8): 1779-1784.

[8]. Mahmud, H.B, Hamid, N.B.A.A., and chia, B.S.1996, High strength Rice Husk Ash- A preliminary investigation. Asia pacific conferences on structural engineering and construction. Pp. 383389.

[9]. Ismail, M.S., A.M. Waliuddin, 1996, effect of rice hush ash on high strength concrete. Construction and building materials, 10(7): 521-526

[10]. Zhang, M.H., and Malhotra, V.M. High performance concrete incorporating rice husk ash as a supplementary cementing material. ACI Mater. J., 1996. 93(6): pp. 629-639.

[11]. Muthadhi, A., Anitha, R., and Kothandaraman, S., Rice Husk Ash Properties and its Uses: A Review, 
Department of Civil Engineering, Pondicherry Engineering College, Puducherry,1.E(1) Journal, 2007.

[12]. Chandrasekar, S., Satyanarayana, Processing, Properties and Applications of Reactive Silica from Rice Husk - an Overview, Journal of Material Science, 2003, 38:P. 3159.

[13]. Mahmud, H.B., Majuar, E., Zain, and Hamid, (2009), Mechanical Properties and Durability of High Strength Concrete Containing Rice Husk Ash. Journal of advanced concrete technology, 79(1):2130 . 